\title{
(Dis)ordered Spaces? Managing the Competing Rights of Children in the Gendered Space of the School Toilet
}

\author{
Sarah Richards and Jessica Clark* \\ Department of Psychology, UK
}

Received: 盋 September 21, 2018; Published: 眥 September 26, 2018

*Corresponding author: Jessica Clark, Department of Psychology, University of Suffolk, Waterfront Building Ipswich Campus, Neptune Quay, Suffolk IP4 1QJ, UK

\section{Introduction}

Rights are often perceived as unproblematic and normative, perhaps particularly in childhood where rights are primarily positioned as protective and participatory. However, in a landscape where the rights of trans* and gender non-conforming persons are an increasing focus, rights are once again revealed as being contested, controversial and in-conflict. While trans* identities are constructed by some as being normative, simply part of the continuum of gender identity, for others, trans* is perceived as 'disorder' both biologically and socially [1]. Here, we take the space of the toilet and its binary structure, as emblematic of wider "mechanisms of gender regulation" [2]. We consider the challenges faced by schools (and other social institutions) in managing toilet spaces and the competing and contested rights of those who lay claim to them.

Toilets in the social sciences operate as contested spaces, variously defined sites for the management of 'dirt', emblematic of impurity and pollution [3], a literal and moral escape from the unacceptable as this pollution is made to disappear [4], a site of hard-won equalities [1], a place for sexual pleasure [5] and a site of peer relations and bullying [6]. Toilets are the spatial realisation of the intersection of private and public [7] where the division of space maps onto the division of bodies and their functions [4]. The gendered nature of the toilet is ubiquitous, emblematic of gender operating as one of the deepest organising principles of western societies. Toilets as technologies of separation appear simple in their binary nature but the space of the toilet is deeply ambiguous - a site of shame and decency, anonymity but interchange, aiming to contain the dirt but themselves considered dirty.

The toilet is a unit of space into which docile bodies are managed and surveyed [8]. They are the material manifestation of the regulatory and dividing practices of gendered bodies. The very doors to such spaces, with their gendered symbols, signify one's right to enter based on an identifiable gender identity [2]. Disciplinary space, Foucault argues condenses masses of bodies into manageable (gendered) spaces. The apparent simplicity of this disciplinary architecture [9] doesn't reveal the dynamic nature of the toilet or indeed the categories of gender that such places reify. Non-gender conforming individuals and trans* persons problematize the essentialised, gender binary that has informed the social order. Trans* identities are still readily constructed as sexual disorders. Even supposedly progressive nations such as Finland, require a diagnosis of Gender Identity Disorder (GID) to access gender reassignment interventions and ultimately surgery. This is also predicated on the sterilisation of these individuals [10]; a powerful example of the maintenance of the social order by encouraging or forcing gender conformity. Controversially, Jeffrey [11] argues that the current 'regime' of trans gendering children as well as adults, (notably amongst the medical profession), is not as rights based as it may first appear. Rather it serves to shore up a heteronormative state and gender binary citizenry.

As Ingrey [2] posits the space of toilet is emblematic of the wider mechanisms of gender regulation performed in social structures at large. The regulation of school toilet spaces, and indeed wider school architecture [12], is thus also inextricably linked to the ways in which childhood itself is regulated. The dominant social construction of childhood still positions children as innocent, pure, vulnerable and unknowing, despite proponents of the 'new' sociology of childhood advocating children as agentic beings and rights bearers [13]. These overriding discourses of 'ideal' childhood require constant surveillance and regulation in order to be maintained. Much like gender, childhood is presumed to be natural, yet requires constant vigilance and surveillance to maintain it in its idealised form [14]. This is particularly visible in spaces such as the toilet where gendered and sexual identities, and sexual and biological knowledge intersect with notions of childhood purity, innocence, and ignorance.

The school toilet thus plays a vital function as a disciplinary space where children learn concrete elements of the dominant, 
gendered, social order. It also functions as a site of anxiety as it has the potential to be incompatible with the prevailing social ideas around childhood. Here, children may be exposed to knowledge about bodies society may not think they should have. Just as children are presumed innocent and pure, the toilet is constructed as a space that is emblematic of dirt, impurity and pollution. Discursively the two appear incompatible, generating tensions around children in toilets, which operate as both public and private spaces.

We conceptualise school toilets here as discursive strategies of gender and sexuality that produce regimes of truth (see also Ingrey [2], Foucault [8], Slater, Jones, and Procter [15]). The presence of the trans* child in this regulated space further problematizes the social ordering of gender and sexuality and thus the spaces along which these lines are bounded. In the context of emerging and solidifying LBGTQ rights for children and adults, how the rights of all groups are accommodated, subordinated and realised in policy and everyday schooling must be managed. The rights of trans* children have emerged in recent years in the school environment as educators, policy makers and academics continue to debate how to accommodate these rights within existing structures. Here, the rights of the cisgender child, the trans* child, the disabled child, the family etc., coalesce into a complex landscape of competing priorities, rights, responsibilities, and needs.

Policies around trans* children and children who identify as non-gender binary unsurprisingly promote, what hitherto has been a marginalised set of identities, the rights of the trans* person [16]. This is encapsulated by the position that all individuals have the right to use the toilets of the gender to which they identify $[16,17]$. The argument being that to deny a transgender young person access to the bathroom corresponding to their gender identity endangers their health and wellbeing [18]. On the face of it, this doesn't appear an unreasonable position, yet it is a contested one. For example, feminist groups argue that such an approach erodes the hard-won rights of women to toilet facilities, which comply with anatomy as well as gender identity [1]. One of the arguments here rests on a presumption of men as defined biologically according to (birth/in-tact) genitalia and that men are innately predatory beings, whose presence in the toilets of women and girls is a threat to their safety. Women are argued to be a majority but vulnerable group requiring protective, special treatment from sexual harassment, abuse and violence, that may manifest itself in women-only spaces [19]. Jeffreys [1] argues that neutralising the gender-binary of toilet architecture puts women at risk, thus women's rights are viewed as being subordinated in favour of the rights of non-gender binary and trans* individuals.

It is not just the supposed safety of women that is argued within these debates but also the safety of children, notably girls. An example from the US of a trans* person identifying as a woman, but retaining male genitalia, making use of a sauna facility also accessed by teenage girls, highlights the heightened anxieties of parents of children being exposed to male anatomy, and by extrapolation sexual imagery and knowledge [20]. The positioning of children as innocent, asexual and unknowing makes gender slippage in 'private' toilet spaces problematic for parents and families. The case of 'Bobby' (formerly Susan), as discussed by Beese and Martin [21], demonstrates how the rights of cisgender children and trans* children can bring parents into conflict as they rally to protect the perceived rights of their children. The parents of the girls sharing the toilet with Bobby in their high school insisted his presence in the toilets and locker rooms violated the rights of their girls to private, women-only spaces. The response was to provide Bobby with private toilet facilities, however this was considered by Bobby's parents as discriminatory. Of note here, is not just the conflict between the rights of groups of children who identify in different ways but the supremacy of the parents' rights. Many schools, notably in the US, will not honour the views of trans* children without parental support. Parents in fact sometimes can even override their child's wishes about their gender identity [22].

An alternative solution often offered to trans* children and their parents is for children to make use of disabled toilet facilities. This is met with a variety of responses. Some disability groups argue that they continue to fight for adequate facilities for disabled persons [15] and that in a disabling society such spaces are precious and hard-earned. Here, the rights of disabled people and the rights of gender non-conforming and trans* individuals are in potential opposition. Some argue that the disabled toilet can operate as a "temporarily queer" space [23]. A respite where gender binaries can be negotiated by the individual. However, others claim that some trans* individuals argue that this marginalises their rights to use facilities which correspond with the gender they identify with and serves to further 'other' an already excluded group. In addition, such an approach does nothing to problematize the organisation of toilets more broadly in line with the dominant gender binary. Furthermore, these spaces are sometimes not accessible to young children in primary schools without legitimate, authorised 'disabled identities'. In public toilet spaces, the disabled toilet, notably in the UK, often requires a radar key for entry; these are available only to those with again, a legitimate, authorised 'disabled identity'.

So how do schools manage these conflicting rights and responsibilities? Policy examples often do little to provide concrete guidance that can be operationalised in the everyday life and organisation of school. Policies instead remain ambiguous leaving key decisions about toilets and other 'private' spaces such as locker rooms, to school leaders. In the US, it is up to school districts to develop a policy response [21] and in the UK, this is often left to individual schools and even to individual children and families, as NAWUST [24] suggest: "Issues surrounding toilets, changing facilities, PE and games lessons, school trips, exchanges and overnight stays should be addressed on a case-by-case basis in consultation with the young person and their family. If in doubt, expert advice should be sought." Schools are thus required to be at the forefront of policy and guidance in a complex and disputed arena. Where new build schools may well have uni-sex toilets [24] and secondary school curricula is becoming more inclusive of trans* identities [25] many established primary schools are left to grapple with competing rights agendas with very little support. Thus, toilets remain part of the gendered, disciplinary architecture of schools 
while their regulation is a dynamic, contested, and emotive space. What remains normative is the marginalisation of the perspectives of children, we thus call for increasing attention to their voices and views. Trans* identities (for children or adults) still constitute 'disorder', whether this is in relation to trans* bodies and biological bodies in contested spaces, or the social landscapes within which competing rights agendas intersect. School toilets, and the children allowed to occupy these spaces, has become emblematic of wider debates about gender identity, conformity and rights.

\section{References}

1. Jeffreys S (2014) The politics of the toilet: A feminist response to the campaign to 'degender' a women's space. Women's Studies International Forum 45: 42-51.

2. Ingrey J (2012) The publis school washroom as analytic space for troubling gender: investigating the spatiality of gender through students self-knowledge. Gender and Education 24(7): 799-817.

3. Douglas M (1966) Purity and Danger. London: Routledge and Keegan Paul.

4. Barcan R (2005) Dirty spaces, communication and contamination in men's toilets. Journal of International Women's Studies 6(2): 7-23.

5. Humphreys L (1970) The Tearoom Trade: Impersonal sex in public places. London: Duckworth.

6. Smith PK, Shu S (2000) What good schools can do about bullying: Findings from a survey in English schools after a decade of research and action. Childhood 7(2): 193-212.

7. Wright Mills C (1959) The Sociological Imagination. Oxford: Oxford University Press.

8. Foucault M (1977) Discipline and Punish: The birth of the prison. Pantheon, New York, USA.

9. Sanders J (1996) Stud: Architectures of Masculinity. New York: Princeton Architectural Press 11-25.

10. Amnesty International UK (2017) Finland must protect trans rights.

11. Jeffreys S (2012) The trans gendering of children: Gender Eugenics. Women's Studies International Forum 35(5): 384-393.
12. Pike J (2008) Foucault, space, and primary school dining rooms. Children's Geographies 6(4): 413-422.

13. Prout A, James A (1997) Constructing and Reconstructing Childhood, Contemporary Issues in the Sociological Study of Childhood. Falmer Press, London.

14.Clark J (2013) Passive, Heterosexual and Female: Constructing appropriate childhoods in the sexualisation of childhood debate. Sociological Research Online 18(2):3.

15. Slater J, Jones C, Procter L (2016) School toilets, queer, disabled bodies and gendered lessons of embodiment. Gender and Education.

16. Mermaids (2018) Resources for Professionals.

17. National Centre for Transgender Equality (2016) Transgender and gender non-conforming students: Your rights at school.

18. Stephens A, Murray E, Stewart S (2016) Supporting Trans Youth: Guidance for supporting trans and non-binary young people in formal and non-formal education: Information for educators, practitioners, administrators and support staff in Northern Ireland. Northern Ireland: SAIL, Genderjam and Youthnet.

19. Victorian Equal Opportunity and Human Rights Commission (2013) Victorian discrimination law, VA, Australia: State of Victoria.

20. Golgowski N (2012) Parents outrage as transgender woman is permitted to use the women's locker room exposing himself to little girls. MailOnline.

21. Beese JA, Martin JL (2018) The bathroom case: creating a supportive school environment for transgender and gender non-conforming students. Journal of Cases in Educational Leadership, 21(2): 65-76.

22. Ford Z (2016) Texas school promises to out trans kids to parents. Think Progress.

23. Munt SR (2001) The butch body, In Holliday R, Hassard J (eds.), Contested Bodies, London: Routledge 95-106.

24. NASUWT (2017) Trans Equality in Schools and Colleges: Advice and Guidance for Teachers and Leaders, NASUWT: The Teachers' Union.

25. UUTISET (2017) Finnish officials push schools to improve gender diversity teaching, leave behind traditional gender roles.
This work is licensed under Creative Commons Attribution 4.0 License

Submission Link: $\quad$ Submit Article

DOI: $10.32474 /$ OAJRSD.2018.01.000122

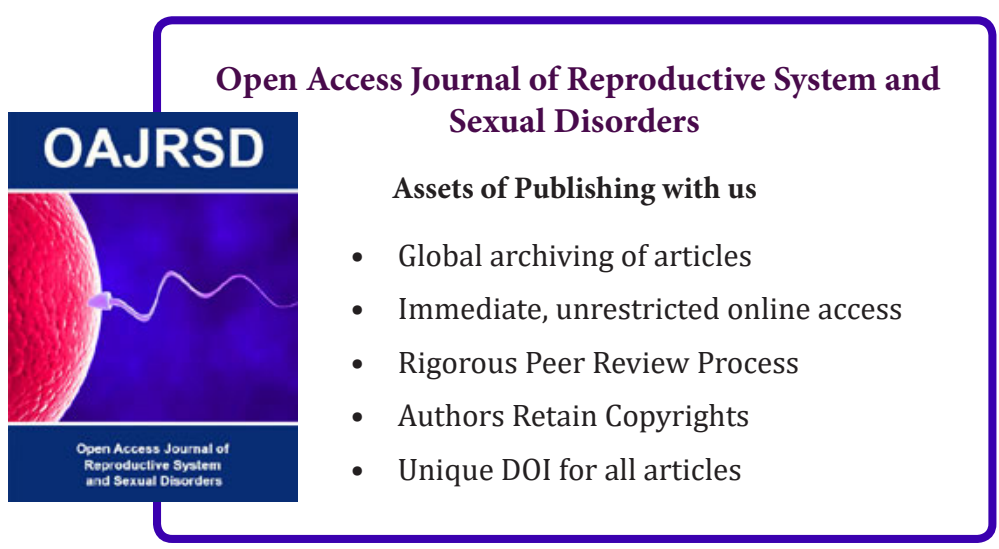

